\title{
US-Carbon Steel (India): Multi-Product Firms and the Cumulation of Products
}

\author{
ALAN SPEAROT * \\ University of California, Santa Cruz \\ DUKGEUN AHN ** \\ Seoul National University
}

\begin{abstract}
One of the key findings in US-Carbon Steel (India) deals with the appropriate method to determine material injury when imported products are subject to simultaneous anti-dumping and countervailing duty (CVD) investigations. Along with addressing a number of legal issues concerning CVD investigations, the Appellate Body clarified restrictions on cross-cumulation of injury, essentially prohibiting the current US practice, and implicitly raising the burden of proof for parallel claims of dumping and subsidies. This decision is justified on economic grounds, where cumulation imposes a counterfactual scenario against which marginal damages of dumping and subsidies by each country cannot be properly evaluated. However, what the legal rulings by the Appellate Body did not recognize is the economic reality that many like products produced by the firms alleged to have received subsidies were selectively absent from the investigation, which more generally complicates the assessment of injury in dumping and subsidy cases.
\end{abstract}

\section{The world market for hot rolled steel}

Hot-rolled steel (HRS) is an intermediate input used in a wide variety of manufacturing applications. The product can be supplied in a variety of formats for direct input use or further processing. These formats mostly involve flat sheets or coils that are integrated with other downstream production processes.

HRS can also be sold in 'mill plate', which is a thick piece of steel that is relatively unprocessed. HRS varies in its material composition, and can also be finished using chemical treatments or other processes to improve strength and/or appearance. The

\footnotetext{
*Email: acspearot@gmail.com

**Email: dahn@snu.ac.kr

We are very grateful to excellent research assistance by Kyounghwa Kim and Ji Yeong Yoo at Seoul National University and the financial support from the National Research Foundation of Korea Grant (NRF 2014S1A3A2043505) as well as Seoul National University Asia Center (SNUAC-2014-007). Thanks to Jennifer Hillman, Tom Prusa, and participants at the WTO Case Law of 2014 workshop at the European University Institute for helpful comments.
} 
different variants of HRS are defined under six four-digit headings of the Harmonized Tariff Schedule (HTS). However, in the Anti-dumping and Countervailing Duties (AD/CVDs) that were the focus of US-Carbon Steel (India), ${ }^{1}$ not all six-digit products within the four-digit headings of the HTS were included in the dispute. Thus, in the graphical summaries below, we will make a distinction between products subject to the AD/CVDs, and those exempt from them.

\subsection{Market summary}

HRS is a major traded product, with $\$ 177$ billion in trade revenues in 2012, and $137 \%$ growth since 2000 . Focusing on the parties subject to the HRS dispute, Figure 1 illustrates the trends in HRS imports to the US, India, and the rest of the world for the period 1992-2013. The solid black lines represent HRS products subject to AD/CVDs, and the dashed lines represent those not subject to the duties but within a similar four-digit category of the HTS (we discuss the precise distinction between these products below).

Prior to the USITC investigation (2000), the US accounted for roughly $30 \%$ of total world imports of HRS products, both those subject to, and exempt from, the AD/ CVDs. In the period after the investigation, the US share of world imports of HRS products fell sharply to about $10 \%$ of total imports. In the left and right panels of Figure 1, we see that HRS products subject to AD/CVDs are fairly 'new' products, at least within the world trading system. Between 1992 and 1995, world demand for imports of HRS products subject to AD/CVDs never exceeded $10 \%$ of total HRS imports. Currently, imports of these products comprise a majority of world HRS trade. In the right panel of Figure 1, it is clear that the two groups within HRS products positively co-vary, suggesting that the products may be subject to the same shocks and/or produced by similar manufacturers. Finally, we see that while India was originally a small importer of HRS products, they have become a larger importer than the US, particularly in those products subject to AD/CVDs. In contrast, the US tends to import the two product groups in approximately equal amounts.

Turning to exports, Figure 2 illustrates the patterns of HRS exports for the US, India, and the rest of world for HRS products subject to AD/CVDs and HRS products exempt from them. Unlike imports, there are clear distinctions between the two countries and the types of HRS products exported before and after the imposition of AD/ CVDs. In the left panel, prior to 2001, we see that the US exported less HRS products subject to AD/CVDs than it did for those exempt from them. After 2003, there was a sharp increase in the production of products subject to AD/CVDs, and the US essentially exported each in equal amounts thereafter. The pattern for India is the exact opposite that of the US, with products being exported in equal (but very low) amounts prior to 2003, and then with production shifting toward products not subject to

1 United States - Countervailing Measures on Certain Hot-Rolled Carbon Steel Flat Products from India, WT/DS436/R, WT/DS436/AB/R, adopted 19 December 2014. 
Figure 1. Imports of HRS products, 1992-2013
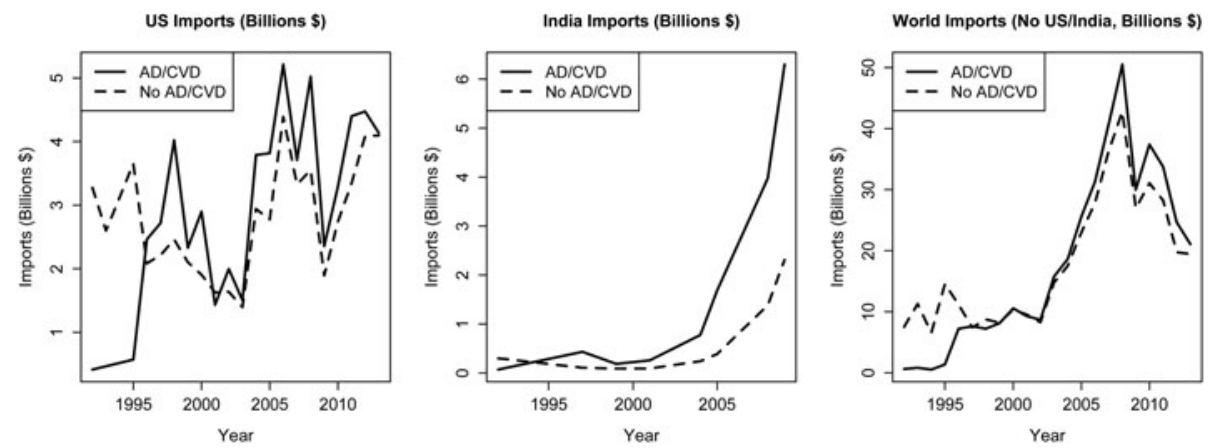

Source: Constructed by the authors with data available from TRAINS.

Figure 2. Exports of HRS products, 1992-2013
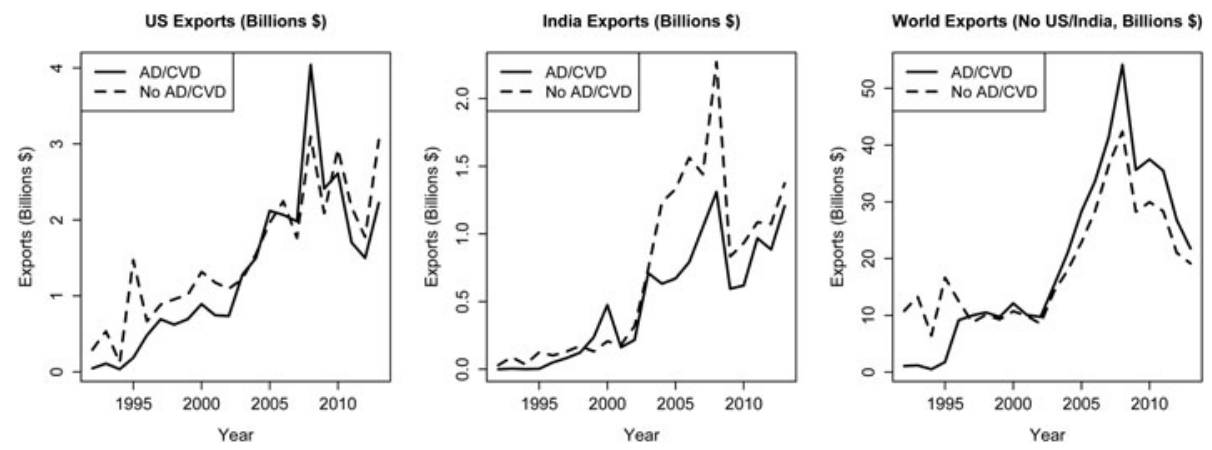

Source: Constructed by the authors with data available from TRAINS.

$\mathrm{AD} / \mathrm{CVD}$ s after 2003. The production switching of India and the US is not coincidental, with both occurring around the same time as US AD/CVDs went into force, and existing contracts could be adjusted to account for the new duties.

To evaluate the case of India and the US more closely, Figure 3 presents three panels of imports from India to the US in all HRS products (left panel), HRS products subject to AD/CVDs (middle panel), and HRS products exempt from AD/ CVDs (right panel). All trade values are in log-differences relative to trade value in 2000. Figure 3 makes clear the issue at hand and the surge in imports that (in part) triggered the AD/CVDs. Relative to the year 2000, the left panel indicates that world imports to the US were relatively stagnant between 1992 and 2000. In contrast, imports from India in all HRS products increased by approximately four $\log$ points over this period. In the middle panel, we see that imports of HRS products subject to AD/CVDs were non-existent prior to 1996, but accounted 
Figure 3. Value of imported HRS to the US, 1992-2013 (year 2000 base)
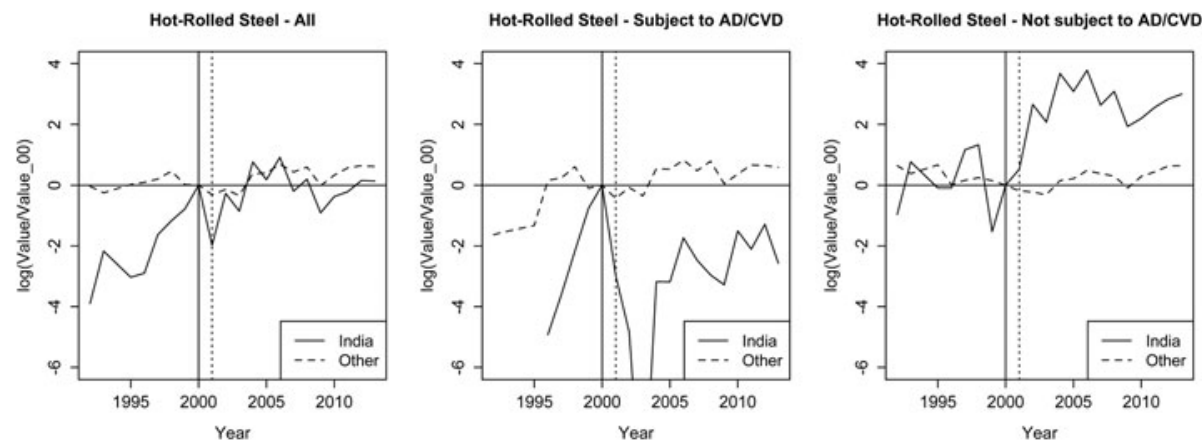

Source: Constructed by the authors with data available from TRAINS.

for substantial growth between 1996 and 2000. There was modest growth in imports in the same categories from non-subject countries. However, growth in these products for non-subject countries occurred prior to 1996.

The vertical dashed line in all panels indicates the final year before AD/CVDs were imposed. In the left panel, we see that the value of HRS imports from India did not change substantially (at least prior to the 2008 economic crisis), despite a large tariff placed on a substantial portion of HRS products. However, in the middle and right panels of Figure 3, we see a clear and astounding switch of imports from subject products (which basically went to zero immediately after the duties were imposed) to HRS products exempt from AD/CVDs.

Taken together, Figures 2 and 3 indicate that large AD/CVDs in the US (and Canada) forced India to switch production, and that this production switch manifested in other markets around the world and remains at present. This suggests that Indian steel producers were able to switch production fairly quickly to a product not subject to the duty, and that any issue of trade diversion will not be limited to those precise product categories subject to the duty.

\section{The investigation and scope of duties}

Dumping and subsidy petitions were filed in 2000 on behalf of a large number of US steel producers. The complaints alleged a wide variety of schemes and subsidies by many countries that caused material injury to US steel producers. Injury across these countries and policies was cumulated per US statute.

For India, the investigation of subsidy allegations focused on nine programs that involved (essentially) export-contingent subsidies or loan guarantees. Important to the analysis of this case is that none of these allegations centered on a particular technology or product within the broad category of HRS. In contrast, the scope of the AD/CVDs focused on a subset of HRS products that varied in the 
Table 1 . HRS products and value share subject to AD/CVDs

\begin{tabular}{llc}
\hline \hline HS4 & Name & AD/CV share (value) \\
\hline 7208 & $\begin{array}{l}\text { Flat-rolled products of iron or non-alloy steel, of a width of } \\
600 \mathrm{~mm} \text { or more, hot-rolled, not clad, plated, or coated }\end{array}$ & 0.627 \\
7210 & $\begin{array}{l}\text { Flat-rolled products of iron or non-alloy steel, of a width of } \\
600 \mathrm{~mm} \text { or more, hot-rolled, clad, plated, or coated }\end{array}$ & 0.190 \\
7211 & $\begin{array}{l}\text { Flat-rolled products of iron or non-alloy steel, of a width of } \\
\text { less than 600 mm or more, non clad, plated, or coated } \\
7212\end{array}$ & $\begin{array}{l}\text { Flat-rolled products of iron or non-alloy steel, of a width of } \\
\text { less than 600 mm or more, clad, plated, or coated }\end{array}$ \\
7225 & $\begin{array}{l}\text { Flat-rolled products of other alloy steel, of a width of } 600 \mathrm{~mm} \text { or more. } \\
\text { Flat-rolled products of other alloy steel, of a width of less than } 600 \mathrm{~mm}\end{array}$ & 0.324 \\
7226 & 0.401 \\
\hline \hline
\end{tabular}

specifications and/or degree of processing. Table 1 reports each four-digit code for HRS, and the share of HS6 products that are subject to AD/CVDs.

The coverage of the AD/CVDs within each HS4 category varies substantially, but the order (as identified through harmonized system codes) focused heavily on basic 'coiled' hot-rolled steel. This distinction is crucial for the end-use, though the distinction within the production process is only important for the final stage. Specifically, whether or not the steel is sheered into uniform sheets, the steel is rolled into coils first. Then, the product can be distributed as is, or further processed using pickling or plating (and then re-coiling), or cut into sheets.

In contrast to the subtle differences in the production process, the downstream use of HRS products subject to the $\mathrm{AD} / \mathrm{CVDs}$ can be quite different. Major manufacturers make clear that the advantage of coiled steel is in the productivity of its end use. Specifically, 'the use of coils generally has more advantages than the use of steel sheets, as a means of improving yield ratio and automating line production. Coil is the material from which the sheet is cut and possesses characteristics which differs from those of a sheet. Thus effective use of coil improves productivity.'2 Thus, the primary focus of the AD/CVDs is HRS products that require (weakly) fewer steps of production and provide (weakly) higher productivity in downstream use.

The decision by the USITC focused on the below-cost pricing on the Indian market (for anti-dumping specifically) and the structure of government programs that implicitly give a subsidy contingent on export performance. In the initial determination for $\mathrm{AD} / \mathrm{CVDs}$, evidence was provided on price-margins that were low, concomitant with losses in the US Steel industry. Future sunset reviews focused on capacity utilization and expected future dumping, but as the US Steel industry had restructured heavily during the 2000s, the industry was in much better

2 See http://www.nssmc.com/product/catalog_download/pdf/U001en.pdf. 
shape. The implication in all this was that unfairly priced imports were in part responsible for previous industry distress, and that keeping the AD/CVDs in place would continue the improved health of the industry. ${ }^{3}$

To evaluate the merits of subsidy determination, Figure 4 summarizes unit values of HRS imports to the US from India (solid lines) and all other countries not subject to AD/CVDs (dashed lines).

From left to right, the three panels illustrate unit values over time for all HRS products, those subject to AD/CVDs against India, and then HRS products exempt from the duties. Clearly, all three panels share the same features. Before the AD/CVDs were issued, India sold HRS products to the US that were $25 \%$ lower in unitvalue than comparable world imports of HRS products. Dumping margins were estimated at a far higher level (34-39\%), based on pricing on the domestic Indian market. CVDs were also imposed at a rate between $9 \%$ and $34.27 \%$.

After the duties were imposed, for a number of years following the order, average unit values from India were more or less similar to imports from the other countries not subject to $\mathrm{AD} / \mathrm{CVD}$. Both results are consistent with the focus on unit values in the original $\mathrm{AD}$ investigation, as well as the subsequent five-year reviews in which the USITC focused on excess capacity and 'likely future injury' as opposed to tangible evidence based on unit values.

As discussed above, the subsidy allegations were not specific to products, but rather specific to firms that appeared to be producing a wide variety of HRS products, both subject to and exempt from the order. The unit values in Figure 4 support the view that the subsidies, if manifested in unit values, would be observed across all products produced by the firm, not only specific products subject to the order. Thus, the question is why the AD/CVDs were levied in this way, and how the WTO, through the SCM Agreement, should evaluate subsidy/dumping allegations against multi-product firms.

\section{Economic analysis}

There is a clear disconnect between the evidence provided by the USITC in support of AD/CVDs and the actual target of the AD/CVDs. Prior to the AD/CVDs, Indian producers were delivering a wide variety of HRS products far below the price set by other manufacturers outside the US. This price advantage was common across all HRS products. The only difference was a much larger growth rate from India to the US in products subject to the orders. However, a larger growth rate in this product category was common in that world imports grew from essentially zero in 1995 to 10 billion in 2000. Though India's growth rate was larger than the rest of the world, it was also a later entrant into this product category. Later entrants tend

3 See 'Hot-Rolled Steel Products from China, India, Indonesia, Thailand, and Ukraine', Publication 4445, January, 2014, European University Institute, page 29. 
Figure 4. Unit value of HRS to US, 1996-2013
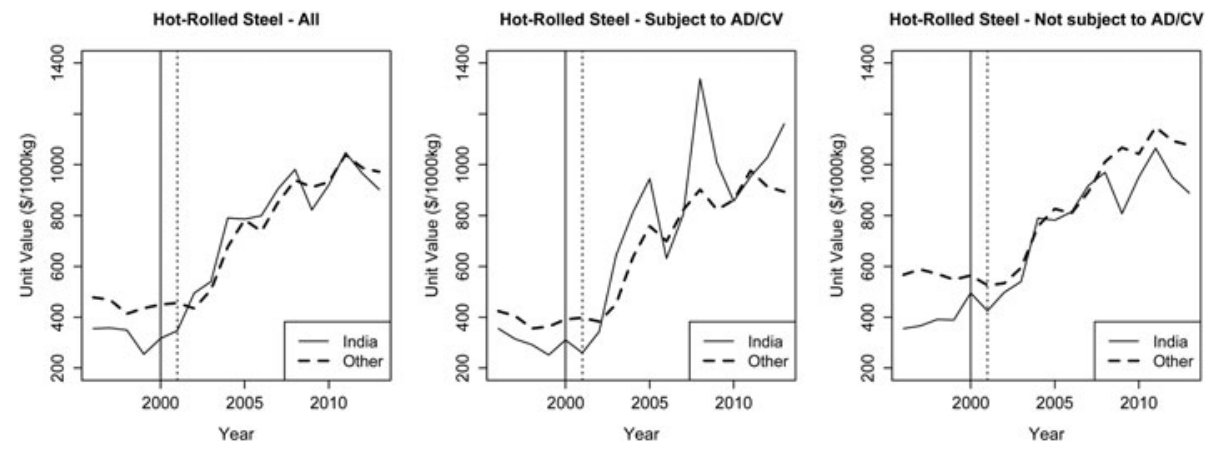

Source: Constructed by the authors with data available from COMTRADE.

to be smaller, and under many revenue functions, can naturally grow faster in response to aggregate shocks. ${ }^{4}$

The AD/CVDs clearly influenced production patterns by the US and India after the agreement, with the US gaining market share in HRS products subject to the orders, and India losing market share in this same category. Within the US market, the orders essentially eliminated imports of HRS products subject to the AD/CVDs from India, and drastically increased imports from India in HRS products exempt from the duties. This suggests that producers were able to switch production to HRS products exempt from the duties. Current industry manuals from Tata Steel and Essar Steel confirm that HRS products in coil and sheet form are both produced by firms subject to the orders. Thus, any subsidy for each firm should affect the incentives to produce very similar products.

\subsection{Short-run vs. long-run gain}

From the discussion of the HRS production process it is clear that the US targeted $\mathrm{AD} / \mathrm{CVD}$ s toward a lower cost product with potential for higher future derived demand. If it is true, as suggested by industry product manuals, that coiled HRS is easier to use in conjunction with superior management practice, the AD/CVDs were targeted toward a more profitable product category, whose customers are more competent firms. Thus, it seems that the motivations of the USITC in choosing definitions of like products at least in part ignored the upstream production process and instead focused on a particular downstream use of a very specific set of HRS products. By doing so, the AD/CVDs did not target the offending behavior in India, but rather a set of varieties chosen by authorities in the US.

It is unclear why the US chose products in this manner, since the efficacy of the duties was questionable when considering the entirety of HRS products. Average 
imports in HRS products from India over the period 2004-2006 were 94\% higher than in the year 2000. This growth in imports from India was in spite of higher unit values that were previously far lower than comparable international products. If the goal of the duties was to limit imports from offending firms and industries in India, the duties were an abject failure.

From this perspective, it is understandable that India raised no objections to the definition of like products proposed by the USITC. ${ }^{5}$ Claiming that more products should be considered under the order would be against the self-interest of India, at least in the short run. Although the production of HRS in sheet form takes one additional step of production, may have lower productivity in end use, and may require finding new customers that do not demand coiled HRS products, existing capacity was equipped for a quick transition to different varieties of HRS.

In the long-run, there is a potentially large downside for India to produce HRS products exempt from the AD/CVDs. From the data, it is clear that HRS products subject to the AD/CVDs are 'new', at least in their status as traded products. Prior to 1996 , the market share of these products (in value) was $10 \%$, quickly rising to $50 \%$ prior and immediately subsequent to the AD/CVDs. Over time, the HRS products subject to the AD/CVDs became the dominant product, with the gap in trade revenues totaling around 40 billion dollars from 2007 to 2013 (though the gap shrank substantially in 2013).

Overall, the AD/CVDs against India (and other nations) by the US and Canada were at least aligned with the fastest-growing product segment in the HRS industry. The duties had very little short run impact on overall HRS imports from India, but drastically shifted production in India to an older product category.

\subsection{Multi-product firms and the SCM Agreement}

The SCM Agreement is largely silent on the issue of multi-product firms, and this is a problem for an objective determination of appropriate AD/CVDs. Broadly, in Article 7.9 of the SCM Agreement, it allows for 'countermeasures, commensurate with the degree and nature of the adverse effects'. To determine the adverse effects, Article 11.2 of the SCM Agreement requires that the complaining party 'include sufficient evidence of ... a causal link between the subsidized imports and the alleged injury'.

Putting aside the typically scant evidence in these subsidy investigations, the focus of this discussion is how the SCM Agreement governs the use of AD/CVDs on a subset of products produced by a firm accused of receiving subsidies. On top of the typical issues of inference, a causal link between subsidized imports and injury is difficult to measure when injury is determined at the firm level but the subsidy is only alleged within a subset of product categories. Coiled and sheet steel products are at least partially substitutable, use very similar inputs, and in many cases are produced within the same plant. But, if a subsidy is 
alleged at the plant level or higher, it is very difficult to separate the impact of the subsidy without detailed cost accounting that is almost certainly not available.

The SCM Agreement almost takes a side on this issue within Article 15 when discussing the determination and assessment of injury. Specifically, Article 15.6 of the SCM Agreement explicitly mentions using the production process, where the 'effect of the subsidized imports shall be assessed ... when available data permit the separate identification of that production on the basis of such criteria as the production process, producers' sales and profits'. Indeed, it would likely be extremely difficult to breakdown capacity utilization and financial information on the basis of the subtle distinction of coiled versus sheet steel. Therefore, the presence of positive evidence, which is required by Article 15.1 of the SCM Agreement, based on capacity utilization or balance sheet information is a particular high (if not impossible) burden for multi-product firms.

\subsection{Cumulative assessment}

An important legal decision in the case relates to the long-standing US practice of cumulating injury across countries subject to both dumping and subsidy cases. ${ }^{6}$ On its face, cumulation does not seem objectionable. If the general goal of AD/CVDs is to alleviate injury due to international measures, it makes sense to measure collectively the impact of these policy measures on domestic performance. However, in terms of evaluating injury attributable to each country, cumulation presents a number of significant problems.

Generally, damages to a domestic industry can be represented by:

$$
d \Pi^{D}=\sum_{j} \frac{d P^{d}}{d q_{j}} d q_{j}
$$

where $d \Pi^{D}$ is the reduction in profits due to a (small) import surge from export sources, indexed by $j$, and $P^{d}$ is the price earned by the domestic industry. ${ }^{7}$ This equation makes clear the requirements necessary to evaluate injury to a domestic industry, which include (1) an estimate of price responsiveness to competing products, and (2) the surge in quantity that is attributable to the offending policies. Assuming for the moment that governments can identify the precise levels of import surge from each source $j$ that is causing injury (which is a big assumption), the primary issue is identifying injury through price movements. Critically, if not all sources $j$ have an equal effect on the domestic price, then evaluating injury under the guidelines of cumulative assessment will not assign damages proportional to actual injury. Indeed, there are a variety of economic reasons why different countries and policies will have a differential effect (per dumped or subsidized unit) on domestic prices.

To illustrate this point, consider a constant-elasticity demand system in an environment with homogeneous goods (i.e. extremely 'like' products). Parameterizing 
the inverse CES demand function as $P=A Q^{-\frac{1}{\sigma}}$, the damage function can be simplified as:

$$
d \Pi^{D}=-\frac{1}{\sigma} A Q^{-\frac{\sigma+1}{\sigma}} \sum_{j} d q_{j}
$$

The clear theoretical result from this equation is that the damages associated with a given trade shock $\sum_{j} d q_{j}$ depend on the current slope of the demand curve, $-\frac{1}{\sigma} A Q^{-\frac{\sigma+1}{\sigma}}$, which itself depends on total quantity. Simply, the slope of the inverse demand curve must flatten as $Q$ rises.

This latter distinction is crucial for assessing injury when cumulating dumped and/or subsidized products from countries of different size. Consider the following example, where a large country such as China subsidizes and dumps a large amount of product on the US market. Since the inverse demand curve flattens with each unit of offending product from China, any subsequent dumped or subsidized products from smaller countries will have a smaller marginal impact than the original marginal impact of China. Thus, under this simple example, the marginal impact of dumping and/or subsidies may vary by country.

However, under cumulation of damages, we are imposing tariff remedies as if all countries imposed the subsidies simultaneously or dumped collectively, which implicitly assigns each country a portion of average damages, rather their respective marginal damage. Put differently, this strategy of assessing damages evaluates all countries against the counterfactual in which nobody is dumping or subsidizing, rather than a counterfactual that is specific to each country eliminating their subsidy or dumping margins.

Within the context of the SCM Agreement, this causes two major problems. First, in contrast to SCM Agreement Article 15.1, cumulation appears to yield damage estimates that are not necessarily commensurate with actual damages specific to each country. Second, cumulation as practiced by the US appears to be inconsistent with SCM Agreement Article 11.2, which requires a causal link between subsidies and injury. Indeed, the counterfactual of removing all subsidies and dumping by all countries for injury analysis is inconsistent with standard practice in econometric identification, where for a given country, all other factors are to be held constant, other than the policy in question. The only way this would be an acceptable identification strategy is if the countries were proven to be colluding on subsidies and dumping. Clearly, cumulation is not isolating the impact of a given country, and thus assuming a counterfactual that is not appropriate for the determination of causation.

Overall, the analysis suggests that cumulation, while well-motivated for assessing aggregate injury, is poorly equipped to evaluate the exact contribution of each country to domestic injury. 


\section{Legal analysis of the WTO decisions}

Legally, this dispute addressed many important aspects of countervailing duty (CVD) proceedings, ranging from procedural elements such as standards to use, facts available to substantive legal factors for CVD investigations such as subsidy determination and cumulative injury assessment. The measures at issue in the panel proceedings included the original investigation and the sunset review as well as five administrative reviews that cover 25 specific actions taken during the period from April 2001 to July $2010 .{ }^{8}$ In addition, the measures at issue also included seven legal provisions of the United States Tariff Act of 1930. India's legal claims against the US laws and practices concerning CVD investigations appear to be the most comprehensive challenge so far in the WTO dispute settlement system. It is also noted that Saudi Arabia joined as a third party along with Australia, Canada, China, and the European Union. ${ }^{9}$

The legal issues of the dispute may be classified into three groups: determination of subsidy, injury assessment, and procedural issues related to the investigation. Although many WTO disputes have already disciplined and clarified the rules and obligations related to countervailing investigations, ${ }^{10}$ the rulings on this dispute made important contributions to CVD jurisprudence.

\subsection{Determination of subsidy}

\subsubsection{Public Body}

The rules for determining a 'public body' within the meaning of Article 1.1.(a)(1) of the SCM Agreement have been elaborated by previous rulings. In the KoreaCommercial Vessels case, the panel ruled that an entity constitutes a public body 'if it is controlled by the government (or other public bodies)' since any action by that entity can be attributable to the government. ${ }^{11}$ Government control may be shown by various factors such as ownership of shares by governments or other public bodies, and government involvement in business operation or governance structures. This ruling was not appealed to the Appellate Body and followed by the panel in the subsequent cases. The Appellate Body in the US-Anti-Dumping

8 The initial CVDs imposed on hot-rolled carbon steel flat imported from India in 2002 have been maintained until 2015 as of writing this article, passing two sunset reviews and the US Court of International Trade proceedings.

9 Third party participation in a panel proceeding has been extensively utilized by some countries such as Australia, Brazil, Canada, China, India, Japan, Korea, Mexico, Norway, Chinese Taipei, Thailand, and Turkey. Saudi Arabia joined in WTO panel proceedings for 27 dispute settlement, although it has not yet been a disputing party. Third party participation, however, may undermine the prospects for early settlement of disputes. See Busch and Reinhardt (2006).

10 Out of 107 disputes citing the SCM Agreement in consultation, as of April 2015, 39 disputes addressed CDV measures or regulations, https://www.wto.org/english/tratop_e/dispu_e/dispu_agreements_ index_e.htm?id=A20\# (visited on 5 April 2015).

11 Korea-Commercial Vessels, WT/DS273/R, para. 7.50. 
and Countervailing Duties (China) case, however, declined such government control test and explained that a public body must be 'an entity that possesses, exercises or is vested with governmental authority'. ${ }^{12}$ It further explained that 'the precise contours and characteristics of a public body are bound to differ from entity to entity, State to State, and case to case'. ${ }^{13}$ Thus evidence that a government exercises meaningful control over an entity and its conduct may serve, in certain circumstances, as evidence that the relevant entity possesses governmental authority and exercises such authority in the performance of governmental functions. In other words, it is not merely the ownership or control over an entity by a government but governmental authority that makes an entity a public body.

In this dispute, the Appellate Body further clarified the criteria to determine a public body as follows:

Whether the conduct of an entity is that of a public body must in each case be determined on its own merits, with due regard being had to the core characteristics and functions of the relevant entity, its relationship with the government, and the legal and economic environment prevailing in the country in which the investigated entity operates. For example, evidence regarding the scope and content of government policies relating to the sector in which the investigated entity operates may inform the question of whether the conduct of an entity is that of a public body. The absence of an express statutory delegation of governmental authority does not necessarily preclude a determination that a particular entity is a public body. Instead, there are different ways in which a government could be understood to vest an entity with 'governmental authority', and therefore different types of evidence may be relevant in this regard. ${ }^{14}$

In this case, India argued that the US Department of Commerce (DOC) improperly focused on the Government of India's (GOI's) 98\% shareholding in the National Mineral Development Corporation (NMDC) to determine NMDC a 'public body'. The Appellate Body ruled that the panel actually erred in its substantive interpretation of Article 1.1(a)(1) by construing the term 'public body' to mean any entity that is 'meaningfully controlled' by a government. It held that the panel erred in endorsing the DOC's public body determination that treats the GOI's ability to control the NMDC as determinative. Although the panel reviewed 'some indicia of control' by the GOI such as shareholding and the GOI's involvement in the selection of directors, the Appellate Body found that the panel did not address the question of 'whether there was evidence that the NMDC was performing governmental functions on behalf of the GOI'.15

Reversing the panel decision, the Appellate Body reviewed whether the DOC's determination that the NMDC is a public body is inconsistent with Article 1.1(a)

$12 \mathrm{WT} / \mathrm{DS} 379 / \mathrm{AB} / \mathrm{R}$, para. 317.

13 Ibid.

14 WT/DS436/AB/R, para. 4.29.

15 Ibid., para. 4.42 . 
(1) of the SCM Agreement. Whereas the DOC determined that 'the NMDC is a mining company governed by the GOI's Ministry of Steel and that the GOI holds 98 percent of its shares', it noted that the DOC did not evaluate 'the relationship between the NMDC and the GOI within the Indian legal order', and the extent to which the GOI in fact 'exercised meaningful control over the NMDC and over its conduct'. ${ }^{16}$ The Appellate Body also noted the lack of the DOC discussion on the NMDC's status as a Miniratna or Navratna company that could have been relevant to the question of 'whether the USDOC's determinations contain a sufficient and adequate evaluation of the relationship between the GOI and the NMDC, and, in particular, the degree of control exercised by the GOI over the conduct of the NMDC and the degree of autonomy enjoyed by the NMDC'. ${ }^{17}$ Therefore, it ruled that the DOC did not provide a reasoned and adequate explanation of the basis for its finding that the NMDC is a public body.

In a way, this decision reminds of the rulings in US-Anti-Dumping and Countervailing Duties (China) that the DOC determination of Chinese stateowned enterprises as public bodies was inconsistent with Article 1.1(a)(1) of the SCM Agreement since it was primarily based on the Chinese Government's majority ownership of the shares in the respective companies. The reason why the DOC appeared to repeat the same mistakes in this case on public body determination as in US-Anti-Dumping and Countervailing Duties (China) is that the DOC decisions challenged in two cases were actually made in a similar time period, despite more than a three year gap between two WTO disputes.

The Appellate Body ruling on public body determination in this case substantially increases the burden for investigating authorities in CVD investigations. For numerous potential public entities, investigating authorities should engage in case-by-case analyses to examine the nature of the relationship with governments and the economic as well as legal environments for the entities at issue. In addition, the lack of more concrete criteria on what kind of, and how much, evidence will suffice in such an examination may engender more legal disputes on this issue. In particular, this issue will become a very important legal element for future CVD actions against Chinese state owned enterprises (SOE). ${ }^{18}$ Considering the difficulty in obtaining pertinent information for Chinese SOEs, the Appellate Body ruling in this case seems to raise another complex challenge for CVD actions against China.

\subsubsection{Financial contribution}

The SCM Agreement specifically defines a 'financial contribution by a government' in Article 1, which includes 'a direct transfer of funds' and 'government provision of goods'. This case raised interesting legal issues concerning the two definitions. 
India argued that the Steel Development Fund (SDF) loans could not be considered 'direct transfers' of funds within the meaning of Article 1.1(a)(1)(i) of the SCM Agreement because the Joint Plant Committee (JPC), formally administering the disbursement and collection of funds, and the day-to-day operations of the SDF, was not a public body. The panel disagreed with India, finding that the SDF Managing Committee, a public body, was directly involved in the provision of SDF loans since it made the decision as to the issuance, terms, and conditions of the loans. India appealed this decision arguing that Article 1.1(a)(1)(i) covers only transfers of funds that are 'direct', which means that 'the action and its consequence must be immediately linked without involving any intermediary or intervening agency'. ${ }^{19}$ India asserted that, where the SDF Managing Committee action merely consists of decision-making on the issuance or terms of the transfer, and this action precedes the actual fund transfer by the JPC, it cannot be 'a direct transfer of funds'. Moreover, India contended that the SDF loans consisted of voluntary contributions from steel producers and thus could not constitute a financial contribution by a government or any public body.

The Appellate Body noted that Article 1.1(a)(1)(i) stipulates that a financial contribution exists where a 'government practice involves' a direct transfer of funds. It held that, in Article 1.1(a)(1)(i):

the meaning of the term 'direct' in relation to a 'transfer of funds' suggests the immediacy of the conveyance of funds, which in turn points to the existence of a close nexus concerning, for instance, the parties to, and/or the actions relating to, the transfer of the funds. At the same time, we have noted that any such immediacy is mitigated by the context provided by a 'government practice' that 'involves' the direct transfer of funds. These latter terms suggest a more attenuated role for a government or public body for purposes of Article 1.1(a)(1)(i) than what would otherwise have been understood through an examination of the phrase 'direct transfer of funds' in isolation. We therefore consider that Article 1.1(a)(1)(i) does not rigidly prescribe the scope of its coverage. Rather, the provision reflects a balance of different considerations to be taken into account when assessing whether a particular transfer of funds constitutes a financial contribution. ${ }^{20}$

Based on such an interpretation principle, it explained that Article 1.1(a)(1)(i) does not require a transfer necessarily to emanate from government title or possession over the transferred resources. Regardless of the source of the resources used to fund the SDF loans, the Appellate Body affirmed that 'those funds were held in an account and could only be issued as loans on terms and conditions as decided by the SDF Managing Committee'. ${ }^{21}$ Accordingly, it agreed with the panel ruling that the actions of the SDF Managing Committee involve a direct transfer of 
funds within the meaning of Article 1.1(a)(1)(i) since the SDF Managing Committee played its role as decision-maker regarding the issuance, terms, and waivers of SDF loans.

In summary, focusing on 'involvement of government practices' instead of 'direct transfer of fund', the Appellate Body ruling substantially broadens the scope of a financial contribution by a government. As the Appellate Body explained from the dictionary definitions, it is true that there is no provision to confine the scope of 'funds' to governmental or public funds. Thus the focus of the analysis was not on the public nature of funds, but rather on the role of a public body in transferring funds sufficiently important to constitute 'involvement of government practices'.

Although this ruling fits well with the Appellate Body function to strengthen the textual interpretation, it may raise some questions of the contextual understanding of Article 1.1(a)(1). It appears that Article 1.1(a)(1)(ii), (iii), and (iv) - albeit the first part of the sentence, 'a government makes payments to a funding mechanism' clearly involve 'governmental' financial resources. So with a different interpretation it may be possible to argue that the four alternative methods stipulated in Article 1.1(a)(1) deal with four major ways for providing governmental resources direct transfer, forgiving government revenues, provision of goods and services, and indirect subsidy through funding mechanisms. Then it seems odd to interpret that 'funds', such as grants, loans, and equity infusion, in Article 1.1(a)(1)(i), transferred by involvement of government practices may not be 'public' funds in nature. Whereas governmental involvement in the transfer of a fund, public or private, would certainly cause distortion in a competitive condition, this ruling invites complicated challenges for determining the nature and extent of such governmental involvement that translates private funds into a government subsidy.

Another issue raised by India is whether a grant of captive mining rights for iron ore and coal by the GOI can be considered a provision of goods within the meaning of Article 1.1(a)(1)(iii) of the SCM Agreement. India argued that, given the 'uncertainty inherent in mining activities' as well as the 'need for significant intervention through private conduct' in extracting the minerals, the 'reasonably proximate relationship' standard applied by the Appellate Body in US-Softwood Lumber IV 22 could not be fulfilled due to too remote a link between the grant of mining rights by the government and the actual iron ore or coal extracted. The panel, however, ruled that the GOI's grant of mining rights 'essentially made those minerals available to, and placed them at the disposal of', the mining entities. ${ }^{23}$ Thus the panel considered that the GOI's grant of mining rights is 'reasonably proximate' to the use of the minerals by the beneficiaries to constitute a provision of a good within the 
meaning of Article 1.1(a)(1)(iii) of the SCM Agreement. The panel also made a distinction between the mining rights at issue, which involve 'the right to extract minerals from known sites', as opposed to more tenuous arrangements such as exploration rights, which involve 'the right to explore or prospect, and, if anything is found, extract it'. ${ }^{24}$

The Appellate Body supported the panel by finding that the panel in fact examined complexity and uncertainty of the mining rights arrangement in assessing whether there is a reasonably proximate relationship between the grant of mining rights and the final extracted goods. Despite the differences between standing timber in US-Softwood Lumber IV and iron ore and coal in this case, it found that 'rights over extracted iron ore and coal follow as a natural and inevitable consequence of the steel companies' exercise of their mining rights'. ${ }^{25}$ Thus the Appellate Body confirmed the panel's conclusion that the government's grant of mining rights constitute a provision of a good within the meaning of Article 1.1 (a)(1)(iii) of the SCM Agreement. It clarified that a provision of a good within the meaning of Article 1.1(a)(1)(iii) is not necessarily physical transfer of goods, but includes rights to use such goods reasonably related to the goods themselves.

\subsubsection{De facto specificity}

India argued that de facto specificity must be vindicated by the fact that the subsidy discriminated in favor of certain enterprises over a comparative set of other similarly situated enterprises. The panel explained that subparagraphs (a) and (c) of Article 2.1 both focus on 'the existence of a restriction on access to the subsidy, in the sense that the subsidy is available to certain enterprises, industries, or groups of enterprises or industries, but not to others'. ${ }^{26}$ The panel ruled that Article 2.1 provides 'no requirement to show that the subsidy is at the same time not available to other, undefined - but similarly situated-entities' ${ }^{27}$ In other words, it held that Article 2 contains no reference to the notion of 'discrimination'.

In fact, the Appellate Body in US-Anti-Dumping and Countervailing Duties (China) ruled that the principles set forth in Articles 2.1(a) and (b) concern the issue of whether the 'conduct or instruments of the granting authority discriminate or not'. ${ }^{28}$ In the panel's view, however, the use of the term 'discriminate' does not suggest that Article 2.1 require an investigating authority to determine whether the access to a subsidy is denied to other, similarly situated entities. The panel explained that, under India's approach, specificity could not be established where the 'certain enterprises' represent the totality of an industry since it would

24 Ibid., para. 4.64.

$25 \mathrm{WT} / \mathrm{DS} 436 / \mathrm{AB} / \mathrm{R}$, para. 4.74.

$26 \mathrm{WT/DS436/R,} \mathrm{para.} \mathrm{7.121.}$

27 Ibid.

$28 \mathrm{WT} / \mathrm{DS} 379 / \mathrm{AB} / \mathrm{R}$, para. 367. 
not be possible to establish that similarly situated entities were excluded from the subsidy.

The Appellate Body further explained that there is no textual basis in Article 2.1(c) for a requirement to identify which enterprises or industries are similarly situated' prior to assessing whether only a part of them have access to the subsidy. When India argued that the Appellate Body in US-Large Civil Aircraft (2nd complaint) required the analysis on de facto discrimination ${ }^{29}$, the Appellate Body explained that the required analysis is not whether there had been discrimination between a limited number of subsidy users, but whether there had been a granting of disproportionately large amounts of subsidy to certain enterprises. In other words, the Appellate Body emphasized that the de facto specificity does not require any discriminatory element in subsidy policies. It means that there is no need for showing similarities or any characteristics of beneficiaries other than limitation of subsidy in terms of access.

Next, India asserted that the phrase 'limited number of certain enterprises' set out in Article 2.1(c) must form a subset of enterprises within a broader group of certain enterprises. Noting that the chapeau of Article 2.1 defines the term 'certain enterprises' as 'an enterprise or industry or group of enterprises or industries', the Appellate Body explained that the ordinary meanings of the terms 'group' and 'certain' do not indicate any numerical threshold to be qualified as a 'group' or 'certain'. Instead it held that the relevant enterprises must be 'known and particularized', but not necessarily 'explicitly identified', and that they may have 'some mutual or common relation or purpose', or 'degree of similarity'. 30 The Appellate Body has acknowledged, however, that any determination of whether a number of enterprises or industries constitute 'certain enterprises' can only be made on a case-by-case basis. Thus, finding that 'limited number' is meant to convey a finite and limited quantity of 'certain enterprises', it concluded that

a limited quantity of enterprises or industries qualifying as 'certain enterprises' must be found to have used the subsidy programme, without requiring that the limited quantity represent a subset of some larger grouping of 'certain enterprises'. Such a reading is also compatible with our contextual understanding of the term 'certain enterprises' and its relationship to the term 'limited number', the latter of which serves to determine whether the known and particularized enterprises or industries can be quantitatively assessed as limited in number. ${ }^{31}$

Despite this clarification, the delineation of specificity still remains very controversial. For example, when tax exemptions are provided to a wide range of - but not all - industries, it is quite difficult to determine how many industries will constitute 
'group of industries' to make the subsidy specific within the meaning of Article 2.1. It will take a very long timr for case-by-case rulings to provide more concrete guidelines on this issue.

\subsubsection{New subsidies}

It is quite a routine practice for the DOC to include new subsidies in annual administrative reviews. India claimed that, by investigating new subsidy programs in annual administrative reviews, the DOC inappropriately expanded the scope of a review contrary to Articles 21 of the SCM Agreement, which provides '[a] countervailing duty shall remain in force only as long as and to the extent necessary to counteract subsidization which is causing injury'. Noting the term 'subsidization' instead of 'a subsidy', the panel considered that nothing in the text of Article 21.1 could be understood necessarily to relate the term 'subsidization' to specific subsidy programs or to limit the meaning of this term to previously examined subsidization. It also noted that the examination of the new subsidy allegations in the DOC practices involved the same product at issue as in the original investigation. In addition, it found that India did not point to any specific obligation in the text of Article 21 breached by examining the new subsidy allegations in administrative reviews.

Moreover, the panel explained that examination of the 'need for the continued imposition of the duty' under Article 21.2 could include not only consideration in terms of subsidy programs in the original investigation but also consideration in terms of new subsidy programs identified in annual administrative reviews since continued imposition of the duty may be 'necessary in the light of new subsidization, even if previously examined subsidization has expired'. ${ }^{32}$ This panel ruling was not actually appealed by India.

Although this ruling confirmed the well-established practices to investigate relevant new subsidy programs in administrative reviews, it did not address more specific criteria that would qualify 'new' subsidy allegations for review investigations. Practically, once a countervailing duty is imposed on a certain product, any kind of new subsidies on the same product may be covered by annual administrative reviews. Therefore, the US system using annual administrative review procedures becomes much more flexible and active than the retrospective trade remedy systems adopted by other countries in that it can quickly adjust to changes in government policies of exporting countries. In contrast, countries employing retrospective trade remedy systems such as the European Union and Korea may investigate new subsides only if specific review requests are compiled by domestic petitioners. The Appellate Body ruling in this case therefore confirmed the primary advantage of the prospective trade remedy system applied only by the United States in the WTO, despite huge administrative costs. ${ }^{33}$

32 Ibid., para. 4.515.

33 For the comparison of retrospective and prospective trade remedy systems, see US DOC (2010). 


\subsection{Injury determination: cumulative assessment}

The US government often carries out both CVD and AD investigations simultaneously on certain products. In such cases, it has been quite controversial whether the US International Trade Commission (ITC) can 'cross-cumulate' injuries caused by dumping to injuries incurred by subsidies, even if dumped imports come from countries that are not subject to CVD investigations. Although it was regularly practiced by the ITC and even mandated by the court decisions, ${ }^{34}$ many WTO members have viewed that the US practices and the relevant laws are inconsistent with WTO obligations. For example, in the 2000 Report on the WTO Inconsistency of Trade Policies by Major Trading Partners, the Japanese government argued that cross-cumulation practices are 'likely to be in contravention of the stipulation against attributing to dumping injury from other factors under Article 3.5 of the Anti-Dumping Agreement'. ${ }^{35}$ This view was indeed shared by some scholars. ${ }^{36}$ On the other hand, the US government specifically proposed to consider "whether the ADA and ASCM should be clarified to expressly provide for the cumulation of dumped imports with subsidized imports, in order to assess the effects of the unfair imports on the domestic industry'. ${ }^{37}$ This issue, however, has not yet been squarely addressed in the Doha rules negotiations. ${ }^{38}$

In this dispute, India argued that Section 1677(7)(G) of the US Statute stipulating cross-cumulation is inconsistent with Article 15 of the SCM Agreement, whereas the United States rebutted that Article 15 is silent about it and thus does not prohibit such cumulative assessment. Section $1677(7)(\mathrm{G})$ of the US Statute provides, in relevant part:

(G) Cumulation for determining material injury

(i) In general

For purposes of clauses (i) and (ii) of subparagraph (C), and subject to clause (ii), the Commission shall cumulatively assess the volume and effect of imports of the subject merchandise from all countries with respect to which-

(I) petitions were filed under section $1671 \mathrm{a}(\mathrm{b})$ or $1673 \mathrm{a}(\mathrm{b})$ of this title on the same day,

(II) investigations were initiated under section $1671 \mathrm{a}(\mathrm{a})$ or $1673 \mathrm{a}(\mathrm{a})$ of this title on the same day, or

(III) petitions were filed under section $1671 \mathrm{a}(\mathrm{b})$ or $1673 \mathrm{a}(\mathrm{b})$ of this title and

34 Bingham \& Taylor Division, Virginia Industries Inc. v United States, 815 F.2d 1482 (Fed. Cir. 1987).

35 METI, 2000 Report on the WTO Inconsistency of Trade Policies by Major Trading Partners, at 71, http://www.meti.go.jp/english/report/downloadfiles/gCT0005e.pdf.

36 For example, Lowenfeld (2008), at 292.

37 WTO, Identification of Additional Issues under the Anti-Dumping and Subsidies Agreements, Paper Submitted by the United States, TN/RL/W/98 (6 May 2003), at 2.

38 There was no specific proposal for amendment of the current text on this issue. See WTO, Draft Consolidated Chair Texts of the AD and SCM Agreements, TN/RL/W/213. 
investigations were initiated under section $1671 \mathrm{a}(\mathrm{a})$ or $1673 \mathrm{a}(\mathrm{a})$ of this title on the same day,

if such imports compete with each other and with domestic like products in the United States market.

On the other hand, Article 15.3 of the SCM Agreement provides:

Where imports of a product from more than one country are simultaneously subject to countervailing duty investigations, the investigating authorities may cumulatively assess the effects of such imports only if they determine that (a) the amount of subsidization established in relation to the imports from each country is more than de minimis as defined in paragraph 9 of Article 11 and the volume of imports from each country is not negligible and (b) a cumulative assessment of the effects of the imports is appropriate in light of the conditions of competition between the imported products and the conditions of competition between the imported products and the like domestic product.

The panel ruled that the provision 'simultaneously subject to countervailing duty investigations' addresses cross-cumulation because the assessment under Article 15.3 should be limited to imports subject to countervailing duty investigations. It also noted that GATT Article VI:6(a) concerns both anti-dumping and countervailing duties, and that the phrase 'effects of the dumping or subsidization, as the case may be' refers to injury caused 'either by the effect of the subsidy (one 'case') or by the effect of dumping (the other 'case'), and not to the effects of the subsidy and of dumping, cumulatively'.

The Appellate Body clarified that 'being subject to countervailing duty investigations is a prerequisite for the cumulative assessment of the effects of imports under Article 15.3'. It explained that since other provisions in Article 15 also refer to specifically 'subsidized imports' instead of 'imports generally', the injury analysis in the framework of Article 15 must be limited to consideration of injury caused by subsidized imports, rather than covering the effects of imports in general. The Appellate Body also concluded that the non-attribution requirement of Article 15.5 of the SCM Agreement does not allow consideration of non-subsidized, dumped imports in a CVD injury analysis. Accordingly, it agreed with the panel finding that the injury analysis of a CVD investigation must be limited to the effects of subsidized imports and should not consider non-subsidized, dumped imports.

On the other hand, the Appellate Body noted that the parties in the panel proceeding did not seriously contest whether Section $1677(7)(\mathrm{G})$ requires or permits cross-cumulation of the volume and effects of subsidized and non-subsidized imports. Despite the limited nature of the parties' submissions, the Appellate Body ruled that the panel failed to comply with its duties under Article 11 of the DSU in failing to articulate clearly the scope of its finding of inconsistency. In competing the legal analysis, it explained that Section $1677(7)(\mathrm{G})(\mathrm{i})$ and the pertinent 
provisions of the US Statute require an investigating authority to undertake 'crosscumulation' in any of the following three scenarios:

1. where petitions to initiate countervailing duty investigations or anti-dumping duty investigations are filed on the same day;

2. where countervailing duty investigations or anti-dumping duty investigations are initiated by the investigating authority on the same day; or

3. where petitions to initiate countervailing duty investigations or anti-dumping duty investigations are filed on the same day and countervailing duty investigations or anti-dumping duty investigations are initiated by the investigating authority.

It explained that if the word 'or' is read in its inclusive sense - i.e. as meaning either one or the other, or both in combination - then the authority shall cumulate the volume and effects of dumped and subsidized imports under Section 1677(7)(G) (i)(I), (II), and (III). But, if the word 'or' is read in its exclusive sense, cross-cumulation would be required only 'if, on the same day, countervailing duty investigations are initiated by petition and anti-dumping duty investigations are initiated by the authority, or vice-versa' because Section $1677(7)(\mathrm{G})(\mathrm{i})(\mathrm{III})$ expressly refers to a situation where petitions are filed and investigations are initiated with respect to $\mathrm{AD}$ and $\mathrm{CVD}$ on the same day. In the light of these reasons, the Appellate Body ruled that, at least, Section $1677(7)(\mathrm{G})(\mathrm{i})(\mathrm{III})$ is inconsistent 'as such' with Article 15 of the SCM Agreement.

Regardless of which interpretation between inclusive and exclusive is correct, the gist of the Appellate Body ruling is to prohibit cross-cumulation practices in injury determinations. From the perspective of legal principles, it appears to perfectly make sense to prohibit cross-cumulation of injuries incurred by subsidies and dumping since the causal elements are clearly different. In practice, however, the distinction between injuries incurred by subsidies and injuries incurred by dumping seems to be impossibly difficult economically or statistically to assess. For example, when subsidized carbon steel products from Country A and dumped carbon steel products from Country B are causing injuries in the carbon steel industry of an importing country, there is almost no economic standard or criteria to differentiate injurious effects of subsidies and dumping for injury indices under Article 15.4 such as declines in output, sales, profits, productivity, return on investments and so on. Further, even if there were a precise statistical identification strategy to distinguish between dumped, subsidized, and other imports, as detailed in Section 3, the measurement and allocation of damages are problematic. Indeed, there is a subtle but important distinction between marginal and average damages of individual policies levied by a collection of countries, and imposing remedies simultaneously will, under all but restrictive assumptions, not be commensurate with the marginal damage of a given country relative to the counterfactual in which they (individually) do not subsidize.

Overall, these practical challenges may lead an investigating authority to take one of two options: (1) provide some arbitrary explanations on how injuries are 
differentiated between subsidies and dumping, or (2) separate CVD and AD cases in terms of timing so that they can decouple two investigations and allege no crosscumulation of injury determination. This issue clearly suggests the need for more coherent application of legal principles and economic analyses.

\section{Conclusion}

To summarize, US-Carbon Steel (India) has identified new challenges for calculating injury in both dumping and subsidy investigations. The presence of multiple products and many countries complicates the identification of causal injury, as required by the SCM Agreement, and consequently the legally permissible remedies under the WTO system. Further, the new limits on cumulation require that governments more accurately assess the marginal injury of a country's dumping and subsidies separately.

However, there is some hope for an appropriate determination of injury in these types of cases. If firm-product specific subsidies are alleged (as outlined in Section 3), it would be possible to evaluate an impact of the subsidies using a triple-difference methodology on domestic pricing data for domestic firms, subject countries, and non-subject countries, all broken down by subsidized and non-subsidized product group. If subsidies were introduced by a particular country for a particular product, prices would have to fall post-subsidy more for subsidized products than unsubsidized products, and this price difference postsubsidy should be more pronounced for countries that were alleged to provide firm-product specific subsidies. Although this is still a high burden, it at least focuses the point of analysis on the particular product within the firm in relation to other products produced by the same firm. Further, this more refined approach may prove useful in an environment where countries may no longer cumulate the effects of alleged dumping and subsidies across multiple countries.

Finally, to appropriately assess injury when many countries are accused of dumping and/or subsidies simultaneously (as in Sections 3.3 and 4.2), one can draw on new advances in multi-country trade models to evaluate the appropriate counterfactuals when subsidies and/or dumping are removed country by country. Although much of the literature focuses on tariffs or generic transport costs, all models are common in that there are exporter-specific shifters that could be used to represent percent changes in subsidization or price undercutting. ${ }^{39}$ Embracing these advances in the empirical implementation of new trade theory would be a step forward in quantifying injury within trade disputes.

39 For example, see Eaton and Kortum (2002), Dekle et al. (2008), Caliendo and Parro (2015), Costinot and Rodriguez-Clare (2014), Ossa (2014), Allen et al. (2014), and Spearot (2015). 


\section{References}

Allen, T., C. Arkolakis, and Y. Takahashi (2014), 'Universal Gravity’, NBER Working Paper, No. 20787.

Arkolakis, C. (2010), 'Market Penetration Costs and the New Consumers Margin in International Trade', Journal of Political Economy, 118(6): 1151-1199.

Busch, M. L. and E. Reinhardt (2006), 'There's a Crowd: Third Parties and WTO Dispute Settlement', World Politics, 58(3): 446-477.

Caliendo, L. and F. Parro (2015), 'Estimates of the Trade and Welfare Effects of NAFTA', Review of Economic Studies, 82(1): 1-44.

Costinot, A. and A. Rodriguez-Clare (2014), 'Trade Theory with Numbers: Quantifying the Consequences of Globalization', Handbook of International Economics, Netherlands: Elsevier.

Dekle, R., J. Eaton, and S. Kortum (2008): 'Global Rebalancing with Gravity: Measuring the Burden of Adjustment', IMF Staff Papers, 55(3): 511-540.

Eaton, J. and S. Kortum (2002), 'Technology, Geography, and Trade', Econometrica, 70(5): 1741-1779.

Lowenfeld, A. F. (2008), International Economic Law, 2nd edn, Oxford: Oxford University Press.

METI (2000) Report on the WTO Inconsistency of Trade Policies by Major Trading Partners, Ministry of Economy, Trade and Industry.

Ossa, R. (2014), 'Trade Wars and Trade Talks with Data', American Economic Review, 104(12): 41044146.

Prusa, T. J. (1998), 'Cumulation and Anti-dumping: A Challenge to Competition', The World Economy, 21(8): 1021-1033.

Qin, J. Y. (2004), 'WTO Regulation of Subsidies to State-Owned Enterprises (SOEs): A Critical Appraisal of the China Accession Protocol', Journal of International Economic Law, 7(4): 863-919.

Spearot, A. (2013), 'Variable Elasticities and Tariff Liberalization', Journal of International Economics, 86: $26-41$.

— (2015), 'Unpacking the Long Run Effects of Tariff Shocks: New Structural Implications from Firm Heterogeneity Models', American Economic Journal: Microeconomics, forthcoming

Tharakan, P. K. M., D. Greenaway and J. Tharakan (1998), 'Cumulation and Injury Determination of the European Community in Antidumping Cases', Review of World Economics, 134(2): 320-339.

US Department of Commerce (USDOC) (2010), 'Relative Advantages and Disadvantages of Retrospective and Prospective Antidumping and Countervailing Duty Collection Systems: Report to Congress', November, http://enforcement.trade.gov/download/rvp/rvp-final-report-to-congress-20101119.pdf (accessed 2 May 2015). 